\title{
Strategi Taman Kanak-Kanak dalam Mengoptimalkan Pembelajaran Masa Pandemi di Kecamatan Nanga Pinoh
}

\author{
Kasihani Lestari ${ }^{\bowtie}{ }^{\bowtie}$ Harun $^{2}$, Pujiyanti Fauziah ${ }^{3}$ \\ Pendidikan Anak Usia Dini, Universitas Negeri Yogyakarta(1,2) \\ Pendidikan Luar Sekolah, Universitas Negeri Yogyakarta(3) \\ DOI: 10.31004/obsesi.v5i2.1014
}

\begin{abstract}
Abstrak
Tujuan dari penelitian ini adalah untuk mendeskripsikan strategi yang dapat digunakan Taman Kanak-Kanak (TK) dalam masa pandemic agar kegiatan dapat berjalan dengan maksimal. Pada penelitian ini dipaparkan hal-hal yang dapat dilakukan Taman Kanak-Kanak seperti, kegiatan belajar, kerjasama dengan orangtua, metode dan strategi pembelajaran yang diterapkan, serta media yang digunakan dalam kegiatan belajar mengajar di masa pandemic. Penelitian ini menggunakan metode deskriptif dengan melakukan survei kepada 35 orang guru dan kepala Taman Kanak-kanak di Kecamatan Nanga Pinoh. Survei dilakukan dengan menyebarkan angket melalui aplikasi perpesanan online WhatsApp selama kurang lebih dua bulan. Berdasarkan hasil temuan penelitian strategi yang diterapkan sekolah yaitu: (1) Kepala Taman Kanak-Kanak menjalankan perannya sebagai pemimpin, manajer, administrator, supervisor, educator, innovator, dan motivator. (2) guru mengemas pembelajaran secara bervariasi mulai dari bentuk pembelajaran yang sesuai, memperhatikan kebutuhan anak, kegiatan yang melatih kemandirian anak, menggunakan media yang sesuai, menggunakan metode yang beragam, dan menjalin kerja sama dengan orang tua.
\end{abstract}

Kata Kunci: strategi; taman kanak-kanak; pandemi covid-19

\begin{abstract}
The purpose of this study is to describe the strategies that can be used in kindergartens (TK) during a pandemic so that activities can run optimally. This research describes things that can be done at Kindergarten such as learning activities, collaboration with parents, learning methods and strategies applied, and the media used in teaching and learning activities during a pandemic. This study used a descriptive method by surveying 35 teachers and heads of kindergarten in Nanga Pinoh District. The survey was conducted by distributing a questionnaire through the Whatsapp online messaging application for approximately two months. Based on the findings of the strategy research applied by the school, namely: (1) The head of kindergarten plays his role as a leader, manager, administrator, supervisor, educator, innovator, and motivator. (2) the teacher packs learning in a variety of ways, starting from the appropriate form of learning, paying attention to children's needs, activities that train children's independence, using appropriate media, using various methods, and cooperating with parents.
\end{abstract}

Keywords: strategies; kindergartens; pandemic covid-19

Copyright (c) 2021 Kasihani Lestari, Harun, Pujiyanti Fauziah

$\triangle$ Corresponding author :

Email Address : lestarikasihani@gmail.com (Yogyakarta, Indonesia)

Received 30 December 2020, Accepted 8 February 2021, Published 9 February 2021

Jurnal Obsesi: Jurnal Pendidikan Anak Usia Dini, 5(2) 2021 | 1951 


\section{PENDAHULUAN}

Virus Corona atau akrab disebut COVID-19 telah memberikan dampak yang sangat buruk bagi semua aspek kehidupan diseluruh belahan dunia tak terkecuali Indonesia. Covid19 yang pertama kali teridentifikasi di Wuhan, China merebak hingga ke Indonesia dan sudah merubah berbagai bidang kehidupan dinegeri ini. Hingga saat ini telah banyak korban jiwa yang tak dapat diselamatkan akibat keganasan COVID-19. Pertanggal 22 Januari 2021 Kementerian Kesehatan Republik Indonesia meliris situasi COVID-19 di Indonesia yaitu terdapat 965,283 orang yang terkonfirmasi positif, 27,453 orang meninggal dunia, dan sebanyak 781,147 orang yang sembuh (sehatnegeriku.kemenkes.go.id). Dampak yang terasapun diberbagai bidang tidak terkecuali dalam dunia pendidikan. Untuk menghentikan lajunya penambahan masyarakat yang terpapar virus Covid-19 ini pemerintah dengan gencar mengeluarkan berbagai peraturan seperti penerapan protocol kesehatan, hingga penerapan kegiatan-kegiatan dilakukan dari rumah, baik pekerjaan maupun pendidikan. Pendidikan yang seyogianya dilakukan di sekolah secara tatap muka akhirnya beralih dilakukan dirumah secara virtual dalam upaya memutuskan mata rantai penyebaran virus corona tersebut. Pendidikan anak usia dini (PAUD) adalah pendidikan awal yang diterima individu diawal masa kehidupannya. Sehingga tidak dapat disamakan dengan pendidikan pada jenjang setelahnya. Anak adalah usia dimana perlu pembelajaran yang konkrit dan harus melibatkan pengalaman langsung. Sesuai dengan prinsip pembelajaran anak usia dini.

Tidak dipungkiri peralihan pembelajaran dari sekolah ke rumah memberikan banyak dampak bagi kualitas pendidikan yang didapat oleh anak. Yusra Tebe melalui Humaniora (2020) kualitas pendidikan menurun akibat dari COVID-19. Hal ini tentu menjadi tugas yang besar bagi sekolah agar pendidikan tetap terus berjalan dan anak-anak tetap merasakan pendidikan yang layak meskipun dilakukan dari rumah. Pengoptimalan pembelajaran ditentukan dari kerjasama dari beberapa pihak inti yaitu kepala Taman Kanak-Kanak, guru, dan juga orang tua. Danim dalam (Saifulloh, M. Muhibbin, 2012) faktor-faktor yang perlu dimiliki oleh sekolah jika ingin meningkatkan mutu yaitu kepimpinan kepala sekolah, guru, siswa, kurikulum, dan jaringan kerjasama.

Guru dituntut sekreatif mungkin dalam mengemas pembelajaran sehingga pesan yang ingin disampaikan lewat kegiatan pembelajaran dapat tersampaikan dengan baik kepada anak. (Botutihe et al., 2021) tenaga pendidik memiliki peran sebagai pembuat rancangan dan orang tua adalah pihak yang menjadi penghubung kegiatan pembelajaran kepada anak. Agar rancangan yang dibuat dapat tersampaikan dengan tepat kepada anak dibutuhkan strategi dan kreativitas dari guru dalam mengemas pembelajaran tersebut. Tenaga pendidik anak usia dini diwajibkan lebih kreatif dalam mengembangkan pembelajaran secara virtual (Nurdin \& Anhusadar, 2020).

Selain guru yang dituntut untuk kreatif dalam mengemas kegiatan pembelajaran, kepala TK sebagai pimpinan sekolah pun turut dituntut dan terlibat dalam merancang strategi yang digunakan dalam pembelajaran di tengah pandemi. Kepala sekolah harus sigap, tanggap, dan bertanggung jawab memperhatikan keberhasilan maupun kegagalan sekolahnya. Keadaan saat ini adalah bagian dari proses pendidikan sehingga menuntut Kepala Taman Kanak-Kanak sebagai pimpinan memiliki dan menjalankan strategi agar kegiatan pendidikan tetap berlangsung dan kualitasnya terus meningkat (Sudrajat et al., 2020). Kualitas kepemimpinan kepala Taman Kanak-Kanak sangat menentukan keberlangsungan sekolah dan kelancaran pendidikan. Kepala Taman Kanak-Kanak harus menjalankan fungsinya dengan sebaik mungkin baik sebelum maupun sesudah pandemic untuk mempertahankan bahkan meningkatkan mutu pendidikan dan kualitas pembelajaran. Bahkan, di masa pandemic ini kepala sekolah harus berperan lebih ekstra. Dalam penelitiannya (Supriadi, 2020) menemukan bahwa kepala taman kanak-kanak menjalankan peranan sebagai administrator menempati skor tertinggi dari peran lainnya sebagai bentuk usaha untuk menaikkan mutu pendidikan. 
Setiap orangtua mengharapkan anak-anaknya mendapatkan pendidikan yang layak dan terbaik. Sehingga pendidikan anak usia dini yang bermutu merupakan idaman dari para orang tua dimana anak mereka akan menuntut ilmu dengan optimal meskipun dimasa pandemic seperti sekarang ini. Tentu saja merupakan tugas dari sekolah yang terdiri dari kepala TK dan guru yang harus berperan penting menentukan strategi-strategi yang tepat yang harus mereka gunakan dalam pembelajaran diera pandemic ini.

Dengan demikian tugas sekolah yang mencakup di dalamnya kepala Taman KanakKanak dan guru merupakan tugas yang tidak mudah dan tidak dapat dianggap enteng. Walaupun pendidik tidak disebut sebagai garda terdepan dalam melawan COVID-19 namun tidak dapat dipungkiri dan diabaikan bahwa guru menjalankan fungsi dan peran yang sangat berat dalam menyiapkan strategi pembelajaran agar dapat berlangsung dengan optimal. Kondisi sekarang ini membuat banyak sekolah yang tidak siap menghadapi pandemi, tidak menyiapkan strategi yang menunjang pembelajaran agar tetap optimal. Sehingga tidak sedikit sekolah yang akhirnya terpaksa tutup karena keterbatasan sumber daya manusia yang dapat menghandle pembelajaran yang menunjang dimasa pandemic. Penerapan strategi yang digunakan oleh sekolah dalam mengoptimalkan pembelajaran anak usia dini ditengah pandemic seperti sekarang ini merupakan kunci keberhasilan sekolah, karena pendidikan merupakan tolak ukur dari kemajuan suatu negara.

Penelitian (Nasution \& Sutapa, 2021) pembelajaran di masa pandemic memanfaatkan media yang dapat menunjang pembelajaran daring dan melakukan kunjungan rumah. Pemberian tugas merupakan metode yang paling banyak digunakan dalam masa pandemic (Nurdin \& Anhusadar, 2020).

Beberapa penelitian di atas menekankan bahwa peranan kepala sekolah dan strategi pembelajaran yang diterapkan guru sangat berpengaruh terhadap pembelajaran dimasa pandemic Covid-19. Oleh sebab itu penelitian ini harus dilakukan untuk melihat strategi yang dilakukan oleh kepala sekolah dan guru dalam mengoptimalkan pembelajaran masa pandemic untuk menambah informasi dan sumber acuan bagi sekolah dalam upaya mengoptimalkan pembelajaran dimasa pandemic.

\section{METODOLOGI}

Penelitian ini menggunakan jenis penelitian deskriptif. Penelitian bertujuan mengamati dan mendeskripsikan aspek dari suatu situasi sebagaimana terjadi secara alami (Dunlock, 1993). Teknik pengumpulan data menggunakan angket. Instrument angket yang digunakan merupakan angket pengembangan dari angket yang sudah ada dan telah melalui uji validitas oleh tiga orang ahli (Expert Judgement) yaitu dua dosen Universitas Negeri Yogyakarta dan kepala Taman Kanak-Kanak Immanuel.

Penelitian ini bertujuan untuk mendeskripsikan strategi yang digunakan Taman kanak-kanak mengoptimalkan pembelajaran dimasa pandemic. Penelitian dilakukan di TK Kecamatan Nanga Pinoh. Instrument penelitian yang digunakan adalah angket terbuka angket dibuat menggunakan google formulir yang disebarkan secara online melalui WhatsApp. Partisipan yang terlibat dalam penelitian ini adalah 5 orang kepala TK dan 30 orang guru.

Angket penelitian untuk kepala sekolah dikembangkan dari konsep-konsep peran kepala sekolah (Mulyasa,2007) sedangkan sedangkan angket untuk guru dikembangkan dari Visual Systems and Autistic Children Peeters dalam (Tissot \& Evans, 2003) dan e-learning readiness of hongkong teachers (Swatman, 2006).

Pengolahan data dilakukan penarikan kesimpulan dengan menggunakan docs.google.com yang secara langsung telah menghasilkan jawaban (Nasution \& Sutapa, 2021). Berikut bagan yang akan menjelaskan alur penelitian. 


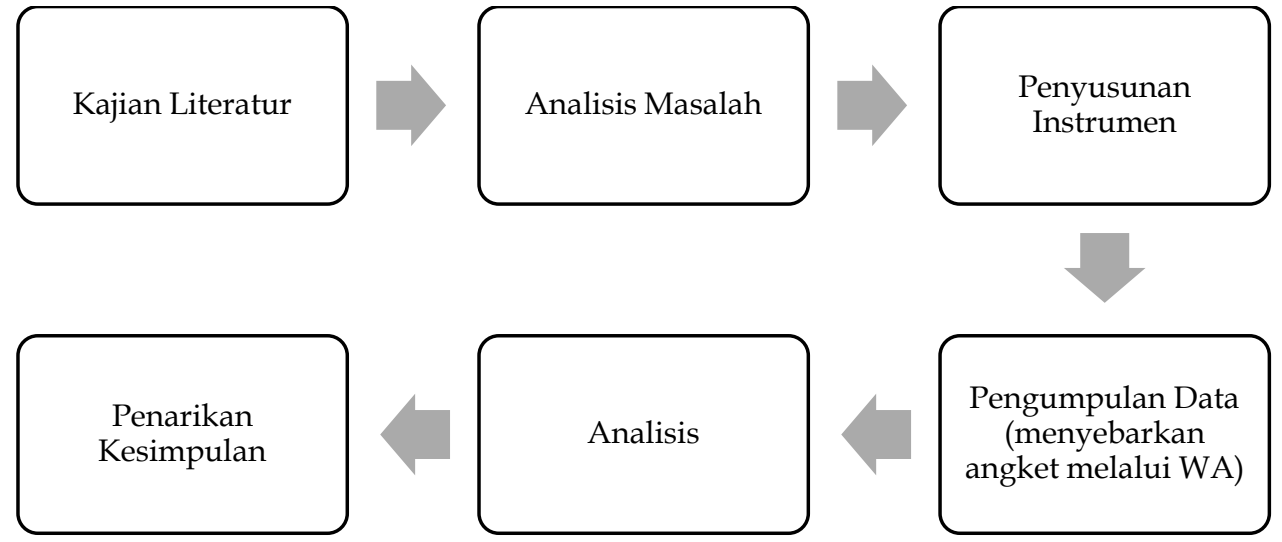

Gambar 1 : Tahapan Penelitian

\section{HASIL DAN PEMBAHASAN}

Hasil penelitian ini bertujuan mendeskripsikan strategi yang digunakan oleh sekolah dalam mengoptimalkan pembelajaran masa pandemic di Kecamatan Nanga Pinoh. Strategi yang dilakukan sekolah dilihat dari peran kepala sekolah dan strategi yang digunakan guru. Gambaran strategi yang digunakan sebagaimana pada tabel 1.

Table 1. Strategi Kepala Taman Kanak-Kanak dalam Mengoptimalkan Pembelajaran Masa Pandemi

\begin{tabular}{|c|c|}
\hline $\begin{array}{l}\text { Peran Kepala } \\
\text { TK }\end{array}$ & Strategi \\
\hline $\begin{array}{l}\text { Sebagai } \\
\text { Pemimpin }\end{array}$ & $\begin{array}{l}\text { Bertanggung jawab terhadap pembelajaran yang dilaksanakan selama } \\
\text { pandemic dengan cara melakukan perencanaan, membuat regulasi sesuai } \\
\text { keputusan kemendikbud. }\end{array}$ \\
\hline Sebagai Manajer & $\begin{array}{l}\text { Kepala Taman Kanak-Kanak mengambil keputusan dan mengatur sistem } \\
\text { pembelajaran yang akan digunakan pada masa pandemic. } \\
\text { Kepala Taman Kanak-Kanak memberikan dukungan kepada guru dengan } \\
\text { menyediakan perlengkapan mengajar, memasang wifi di sekolah, menyediakan } \\
\text { kuota untuk guru, menyediakan fasilitas shooting video pembelajaran. }\end{array}$ \\
\hline $\begin{array}{l}\text { Sebagai } \\
\text { Administrator }\end{array}$ & $\begin{array}{l}\text { Kepala Taman Kanak-Kanak melakukan administrasi seperti mengoreksi } \\
\text { rencana pelaksanaan pembelajaran (RPP), mengevaluasi pembelajaran yang } \\
\text { telah dilaksanakan, membuat laporan kegiatan ke Yayasan dan dinas } \\
\text { pendidikan. }\end{array}$ \\
\hline $\begin{array}{l}\text { Sebagai } \\
\text { Supervisor }\end{array}$ & $\begin{array}{l}\text { Melakukan pengawasan kegiatan pembelajaran seperti melakukan supervisi } \\
\text { pada guru untuk melihat bagaimana cara guru mengajar, apa media yang } \\
\text { digunakan, dan sejauh mana tujuan pembelajaran tercapai. }\end{array}$ \\
\hline $\begin{array}{l}\text { Sebagai } \\
\text { Edukator }\end{array}$ & $\begin{array}{l}\text { Kepala Taman Kanak-Kanak terlibat dalam memberikan pendidikan kepada } \\
\text { anak. menjadi narasumber dalam kegiatan pembelajaran daring. }\end{array}$ \\
\hline Sebagai Inovator & $\begin{array}{l}\text { Kepala Taman Kanak-Kanak memberikan pelatihan Teknologi dan Informasi } \\
\text { untuk menunjang pembelajaran dimasa pandemic sehingga muncul kreasi- } \\
\text { kreasi baru yang dapat dituangkan untuk memperlancar pembelajaran. }\end{array}$ \\
\hline $\begin{array}{l}\text { Sebagai } \\
\text { Motivator }\end{array}$ & $\begin{array}{l}\text { Kepala Taman Kanak-Kanak memberi contoh teladan kepada guru seperti tetap } \\
\text { melaksanakan tugas dan datang tepat waktu walaupun tidak ada anak-anak } \\
\text { yang datang ke sekolah. Mengadakan pembinaan kerohanian dan kesehatan } \\
\text { kepada guru, staff dan karyawan. Memberikan reward seperti makan bersama } \\
\text { diakhir semester untuk menghargai perjuangan semua tim dalam } \\
\text { mensukseskan pembelajaran online. }\end{array}$ \\
\hline
\end{tabular}

Salah satu penentu keberhasilan suatu sekolah adalah bagaimana cara kepala sekolah dalam memimpin. Kepala sekolah mengambil peranan yang amat penting dalam keberlangsungan pendidikan (Sudrajat et al., 2020). Berdasarkan tabel 1 dapat dilihat bahwa 
strategi yang digunakan kepala Taman Kanak-Kanak adalah dengan memainkan dan menjalankan perannya sebagai kepala sekolah, yaitu:

Sebagai seorang pemimpin kepala Taman Kanak-Kanak memiliki peran yang sangat besar dalam mempertanggung jawabkan keberlangsungan pendidikan. salah satu hal yang perlu dilakukan adalah merencanakan dengan baik sebelum mengambil keputusan strategi apa yang akan digunakan untuk menyikapi suatu keadaaan. Penelitian (Sudrajat et al., 2020) menemukan hasil bahwa pengambilan keputusan merupakan strategi yang mengambil peran penting dalam meningkatkan mutu pendidikan. penelitian yang dilakukan oleh (Chan, 2018) menemukan bahwa kemampuan perencanaan yang efektif merupakan salah satu faktor yang memenuhi kepemimpinan strategis di taman kanak-kanak, sebagai pemimpin, kepala taman kanak-kanak harus mampu menentukan secara tepat langkah-langkah untuk menangani masalah secara efektif.

Sebagai manager setelah merencanakan, perlu adanya pengambilan keputusan yang harus dilakukan dengan yakin dan tepat. (Chan, 2018) mengemukakan kemampuan pemimpin dalam manajemen yang efektif menjadi kompeten dalam melihat keterkaitan masalah dan dampak jangka panjangnya sehingga dapat mengambil keputusan dengan tepat.

Sebagai seorang pemimpin, kepala taman kanak-kanak memainkan peran di belakang layar. Mengerjakan administrasi tampaknya seperti hal yang mudah, namun kenyataannya perlu ketelitian, konsentrasi dan bahkan memakan waktu yang cukup banyak. Administrasi tidak hanya dilakukan setelah kegiatan namun sebelum kegiatan kepala Taman kanak-kanak telah lebih dahulu harus memeriksa apakah layak dilaksanakan, bagaimana persiapannya dan kemudian setelah kegiatan pun harus melakukan evaluasi kembali. Hal ini sejalan dengan temuan (Aubrey et al., 2013) administrasi bahkan dilakukan sebelum sekolah dimulai dan bahkan jika kegiatan administrasi yang tidak dapat diselesaikan di sekolah akan dilanjutkan di rumah.

Sebagai supervisor kepala Taman Kanak-Kanak menjalankan fungsi sebagai pengawas dan pengamat kegiatan yang dilakukan. Apakah sudah berjalan sesuai perencanaan dan apakah tujuan dari pembelajaran tersampaikan dengan benar kepada anak. kepala sekolah berperan mengamati kegiatan dan mengoreksi jika ada yang salah (Fitrah, 2017).

Bukan hanya sebagai pemimpin, kepala Taman Kanak-Kanak juga terlibat dalam perannya sebagai educator dalam pembelajaran dimasa pandemic. Salah satu contoh kegiatan yang dilakukan adalah menjadi narasumber pada tema pekerjaan. Kepala Taman KanakKanak memberikan informasi terkait pekerjaan yang dilakukan sebagai seorang kepala sekolah. Temuan (Mohammady, 2018) kepala sekolah sebagai pendidik patut memperhatikan kepada siapa pendidikan diberikan, salah satunya adalah kepada siswa dan yang tidak kalah penting bagaimana cara kepala sekolah menjalankan fungsi tersebut.

Kepala Taman Kanak-Kanak perlu memikirkan terobosan-terobosan apa yang harus dilakukan untuk menghadapi keadaan-keadaan tertentu seperti pandemic saat ini sehingga pembelajaran tidak terhenti dan anak dapat terus belajar meskipun situasi tidak mendukung untuk datang ke sekolah. Dalam hal ini yang dilakukan kepala Taman Kanak-Kanak adalah memberi pelatihan ilmu dan teknologi yang saat ini merupakan cara paling banyak digunakan untuk memperlancar pembelajaran. penelitian yang dilakukan oleh (Putra, 2014)menemukan bahwa sebagai innovator kepala sekolah menerapkan ide-ide dan gagasan-gagasan baru serta memberikan bimbingan dalam menerapkan ide tersebut.

Kepala Taman Kanak-Kanak sebagai pemimpin harus mempunyai cara yang dapat memotivasi dan memberi contoh agar guru, staff dan karyawannya dapat menjalankan tugas mereka dengan baik, meskipun keadaan pada saat ini kurang mendukung karena adanya pandemic. Sehingga guru, staff, dan karyawan merasa kerja keras mereka dihargai dan dengan demikian mereka akan berusaha lebih keras lagi untuk memberikan yang terbaik. Penelitian (Fitrah, 2017) strategi yang tepat sangat diperlukan untuk memotivasi guru menjalankan tugasnya dengan baik. 
Tabel 2. Strategi Guru dalam Mengoptimalkan Pembelajaran Masa Pandemi

\begin{tabular}{|c|c|}
\hline Strategi Guru & Strategi \\
\hline $\begin{array}{l}\text { Menerapkan bentuk } \\
\text { pembelajaran yang } \\
\text { sesuai } \\
\text { Kegiatan pembelajaran } \\
\text { sesuai kebutuhan } \\
\text { anak. }\end{array}$ & $\begin{array}{l}\text { Guru memberikan kegiatan pembelajaran dalam bentuk yang beraneka } \\
\text { ragam seperti pembelajaran dalam jaringan, pemberian tugas, } \\
\text { kunjungan rumah, penggunaan modul, dan tatap muka berkelompok. } \\
\text { Guru melihat kegiatan pembelajaran pada tahun sebelumnya dan } \\
\text { kemudian seperti mengajari menempel, menggunting, menggambar, } \\
\text { mewarnai, menebalkan garis, dan menulis permulaan. Kemudian } \\
\text { membuatnya sesederhana mungkin sehingga dapat dipahami anak. } \\
\text { Membuat pembelajaran sesuai tema dan kejadian yang terjadi saat ini }\end{array}$ \\
\hline $\begin{array}{l}\text { Kegiatan yang melatih } \\
\text { kemandirian anak }\end{array}$ & $\begin{array}{l}\text { Guru memberikan tugas seperti kegiatan sehari-hari di rumah seperti } \\
\text { meminta anak menyiapkan dan merapikan perlengkapan belajar } \\
\text { sendiri dan meminta orangtua untuk merekamnya. } \\
\text { Guru membuat video panduan dan meminta anak membuat karya dari } \\
\text { kertas origami dan meminta orangtua merekamnya } \\
\text { Memberikan worksheet sesuai usia anak. } \\
\text { Guru membagikan bundle yang isinya aktivitas yang dapat dikerjakan } \\
\text { anak sesuai tema } \\
\text { Meminta anak melakukan kegiatan life skill seperti memakai baju } \\
\text { sendiri }\end{array}$ \\
\hline $\begin{array}{l}\text { Penggunaan media } \\
\text { yang sesuai }\end{array}$ & $\begin{array}{l}\text { Guru menggunakan media audio visual, laptop, LCD, Speaker, } \\
\text { memanfaatkan aplikasi zoom meeting, whatsapp, microsoft team, buku } \\
\text { paket, worksheet. } \\
\text { Memanfaatkan media yang ada disekitar anak }\end{array}$ \\
\hline $\begin{array}{l}\text { Penerapan metode } \\
\text { yang bervariasi }\end{array}$ & $\begin{array}{l}\text { Guru menerapkan metode sesuai dengan kegiatan pembelajaran. } \\
\text { metode-metode yang digunakan seperti video pembelajaran, } \\
\text { demonstrasi, pemberian tugas, bercakap-cakap, bercerita, diskusi, } \\
\text { tanya jawab. } \\
\text { Guru memberi contoh terlebih dahulu melalui video pembelajaran } \\
\text { maupun secara langsung di aplikasi kemudian meminta anak } \\
\text { melakukan hal yang sama. } \\
\text { Mengarahkan anak melakukan kegiatan melalui aplikasi zoom }\end{array}$ \\
\hline $\begin{array}{l}\text { Menjalin kerjasama } \\
\text { dengan orangtua }\end{array}$ & $\begin{array}{l}\text { Guru menghubungi orangtua secara rutin untuk mengetahui } \\
\text { perkembangan dan kendala yang dialami anak dalam pembelajaran } \\
\text { Guru memberi arahan terkait kegiatan yang akan dilakukan anak } \\
\text { sehingga orangtua tidak salah memberi instruksi kepada anaknya. } \\
\text { Mengunjungi rumah anak. } \\
\text { Guru mewajibkan orangtua melakukan pengawasan dalam kegiatan } \\
\text { pembelajaran. }\end{array}$ \\
\hline
\end{tabular}

Tabel 2 menjelaskan strategi yang digunakan guru ada berbagai macam. Masa pandemic membuat guru harus bekerja dua kali lebih berat dari sebelum pandemic. Pembelajaran harus dikemas dalam bentuk yang menarik dan dapat mencapai tujuan yang sudah ditetapkan serta tetap harus memperhatikan protocol kesehatan. Bentuk pembelajaran dapat dikemas seperti melakukan pembelajaran secara online dengan memanfaatkan aplikasi seperti zoom meeting, whatsapp, dan Microsoft team, guru memberikan tugas yang harus dikerjakan anak di rumah, memberikan modul sebagai panduan bagi orang tua dalam membimbing anak melakukan kunjungan ke rumah anak, dan guru juga melakukan tatap muka berkelompok dengan tetap mematuhi protocol kesehatan. Hasil temuan penelitian (Pramling Samuelsson et al., 2020) guru membuat buku pegangan digital, menyampaikan pemberitahuan melalaui website dan aplikasi online, membuat video pembelajaran seperti menyanyi dan membaca cerita. Selain pembelajaran melalui aplikasi kunjungan ke rumah anak juga merupakan salah satu alternatif yang dilakukan oleh guru agar anak tetap merasa dekat dengan guru dan tidak jenuh dengan pembelajaran yang dilakukan secara daring atau online. 
Guru juga dapat melihat secara langsung perkembangan anak selama belajar di rumah. hasil temuan penelitian (Suhendro, 2020) kegiatan kunjungan ke rumah anak merupakan kegiatan yang bisa dimanfaatkan guru untuk mengetahui kendala yang dialami anak dan membantu menyelesaikannya serta menjadi kesempatan bagi guru menilai perkembangan anak.

Kondisi sekarang ini membuat pembelajaran tidak dapat dilakukan secara langsung. Hal ini mempengaruhi perkembangan anak, oleh karena itu guru perlu mengemas pembelajaran yang dapat menstimulasi perkembangan anak. (Ita, 2018) pembelajaran yang dibuat oleh guru harus mengacu pada kebutuhan anak.

Kemandirian perlu dilatih sejak dini agar anak tidak selalu bergantung kepada orang lain. Upaya yang dapat dilakukan guru untuk melatih kemandirian anak beraneka ragam, seperti melalui kegiatan di rumah sehari-hari, membuat hasil karya sederhana, dan pemberian tugas. Penerapan pembelajaran melalui kegiatan praktek kegiatan pembelajaran kehidupan dapat mengembangkan kemandirian anak (M. E. Safitri et al., 2018). Penelitian (Syahindra et al., 2020) pada masa pandemic kemandirian anak ditanamkan melalui pemberian tugas dari guru.

Konsep pembelajaran anak usia dini adalah belajar yang konkret. Ketika menjelaskan pembelajaran kepada anak perlu adanya media yang dapat membantu anak memahami materi yang disampaikan. Oleh sebab itu media sangat dibutuhkan dalam pembelajaran. ditambah lagi dengan kondisi sekarang ini, media pembelajaran yang digunakan lebih banyak berbasis aplikasi agar dapat menunjang pembelajaran dengan baik. Temuan (A. Safitri et al., 2020) kegunaan media pembelajaran adalah agar pembelajaran dapat tersampaikan sesuai dengan tujuan. Pada masa pandemic seperti ini, media yang dapat menunjang pembelajaran agar dapat terlaksana secara maksimal adalah media pembelajaran berbasis aplikasi seperti pada tabel 2 yang banyak digunakan guru yaitu zoom meeting, whatsapp dan Microsoft team. Hasil penelitian (Nasir et al., 2020) penggunaan teknologi informasi dapat meningkatkan mutu pendidikan dimasa pandemic.

Anak menyukai pembelajaran yang dilakukan dengan metode yang bervariasi. Melalui variasi metode tersebut anak akan merasa penasaran dan tertarik untuk mendengarkan dan mengikuti pembelajaran. berdasarkan hasil penelitian, metode yang digunakan guru bervariasi yaitu video pembelajaran, demonstrasi, pemberian tugas, bercakap-cakap, bercerita, diskusi, tanya jawab. Hasil penelitian (Utami, 2020) adanya perbedaan hasil pembelajaran menulis yang dilakukan dengan menggunakan metode dengan anak yang tidak diberi perlakuan.

Menjalin hubungan kerjasama dengan orangtua sangat dibutuhkan. Saat ini orangtualah yang berperan banyak mendampingi anak di rumah. kerjasama antara sekolah dengan orangtua akan memberikan dampak yang baik dalam pendidikan anak. berdasarkan penelitian (Hapsari et al., 2020) kerjasama yang dilakukan antara sekolah dengan orangtua adalah komunikasi yang bertujuan agar pendidikan yang diberikan kepada anak dapat terlaksana dalam situasi apapun. keterbatasan guru ketika melakukan pembelajaran melalui aplikasi dapat diperbaiki dengan bantuan orangtua untuk menyampaikan pesan pembelajaran kepada anak. oleh sebab itu, komunikasi sangat penting dilakukan oleh guru dan orangtua.

\section{SIMPULAN}

Hasil temuan penelitian menunjukkan bahwa strategi Taman Kanak-Kanak dalam mengoptimalkan proses pembelajaran meliputi peran kepala sekolah dan strategi pembelajaran guru selama pandemi telah berhasil berjalan dengan optimal dengan pencapaian terkait manajemen kepala sekolah dan kegiatan pembelajaran yang sesuai kebutuhan siswa. Komunikasi yang baik sangat dibutuhkan terutama kepada orang tua anak sehingga proses pembelajaran dapat berjalan optimal. 


\section{UCAPAN TERIMA KASIH}

Terimakasih kepada guru-guru Taman Kanak-Kanak di Kecamatan Nanga Pinoh yang telah bersedia meluangkan waktu mengisi angket penelitian ini. terimakasih pula kepada Prof Harun dan Dr Pujiyanti Pauziah selaku pembimbing dalam penulisan artikel ini.

\section{DAFTAR PUSTAKA}

Aubrey, C., Godfrey, R., \& Harris, A. (2013). How Do They Manage? An Investigation of Early Childhood Leadership. Educational Management Administration and Leadership, 41(1), 529. https:// doi.org/10.1177/1741143212462702

Botutihe, S. N., Smith, M. Bin, Kasan, I. A., \& Hilala, R. (2021). Strategi Pembelajaran Physical Distancing PAUD dalam Menghadapi Pandemi Covid19. 5(2), 1536-1543. https:// doi.org/10.31004/obsesi.v5i2.919

Chan, C. W. (2018). Leading today's kindergartens: Practices of strategic leadership in Hong Kong's early childhood education. Educational Management Administration and Leadership, 46(4), 679-691. https:/ / doi.org/10.1177/1741143217694892

Dunlock, H. L. (1993). Research Design : Descriptive Research Definitions of. Journal of Pediatric Oncology Nursing, 10(4), 154-157.

Fitrah, M. (2017). Peran Kepala Sekolah Dalam Meningkatkan Mutu Pendidikan. Jurnal Penjaminan Mutu, 3(1), 31. https:// doi.org/10.25078/jpm.v3i1.90

Hapsari, S. M., Sugito, \& Fauziah, P. Y. (2020). Jurnal Pendidikan Progresif Parent's Involvement in Early Childhood Education during the Covid-19. 10(2), 298-311. https:// doi.org/10.23960/jpp.v10.i

Ita, E. (2018). JDPP. 6(1).

Mohammady, Z. A. (2018). Peran Kepala Sekolah Dalam Mengembangkan Mutu Budaya $\begin{array}{llll}\text { Organisasi. Muslim Heritage, } & 2(2),\end{array}$ https:// doi.org/10.21154/muslimheritage.v2i2.1118

Nasir, N., Bagea, I., Sumarni, S., Herlina, B., \& Safitri, A. (2020). Memaksimalkan Fitur "Breaking Rooms" Zoom Meeting pada Pendidikan Anak Usia Dini di Masa Pandemi Covid-19. Jurnal Obsesi: Jurnal Pendidikan Anak Usia Dini, 5(1), 611. https:// doi.org/10.31004/obsesi.v5i1.662

Nasution, S. T., \& Sutapa, P. (2021). Strategi Guru dalam Menstimulasi Keterampilan Motorik AUD Pada Era Pandemi Covid 19. 5(2), 1313-1324. https:// doi.org/10.31004/obsesi.v5i2.849

Nurdin, N., \& Anhusadar, L. (2020). Efektivitas Pembelajaran Online Pendidik PAUD di Tengah Pandemi Covid 19. Jurnal Obsesi : Jurnal Pendidikan Anak Usia Dini, 5(1), 686. https:// doi.org/10.31004/obsesi.v5i1.699

Pramling Samuelsson, I., Wagner, J. T., \& Eriksen Ødegaard, E. (2020). The coronavirus pandemic and lessons learned in Preschools in Norway, Sweden and the United States: OMEP policy forum. International Journal of Early Childhood, 52(2), 129-144. https:// doi.org/10.1007/s13158-020-00267-3

Putra, J. A. (2014). Peran Kepala Sekolah Sebagai Inovator Di Sekolah Menengah Pertama Negeri Kota Pariaman. Jurnal Administrasi Pendidikan, 2, 347-355.

Safitri, A., Kabiba, K., Nasir, N., \& Nurlina, N. (2020). Manajemen Pembelajaran bagi Anak Usia Dini dalam Meningkatkan Kualitas Pembelajaran. Jurnal Obsesi : Jurnal Pendidikan Anak Usia Dini, 5(2), 1209-1220. https://doi.org/10.31004/obsesi.v5i2.811

Safitri, M. E., Ahmad, K. I., \& Saleh, M. (2018). Development of Child Independence Through Model Picture and Picture, Examples Non Examples Model and Practical Method Directly Activities of Learning Practical Life in Group B Kasih Ibu Kindergarten, Banjarmasin, Indonesia. European Journal of Education Studies, 5(7), 64-80. https:// doi.org/10.5281/zenodo.1494229

Saifulloh, M. Muhibbin, Z. H. (2012). Strategi peningkatan mutu pendidikan di sekolah. 5(2), 206218. 
Sudrajat, C. J., Agustin, M., Kurniawati, L., \& Karsa, D. (2020). Strategi Kepala TK dalam Meningkatkan Mutu Pendidikan pada Masa Pandemi Covid 19. Jurnal Obsesi : Jurnal Pendidikan Anak Usia Dini, 5(1), 508. https:/ / doi.org/10.31004/obsesi.v5i1.582

Suhendro, E. (2020). Strategi Pembelajaran Pendidikan Anak Usia Dini di Masa Pandemi Covid-19. Jurnal Golden Age, 5(3), 133-140.

Supriadi, O. (2020). Peranan Kepala PAUD dalam Penyelenggaraan Pendidikan Sebelum dan Saat Terjadi Pandemi Covid-19. Jurnal Obsesi : Jurnal Pendidikan Anak Usia Dini, 5(1), 841-856. https://doi.org/10.31004/obsesi.v5i1.727

Swatman, P. M. C. (2006). e-Learning Readiness of Hong Kong Teachers. February.

Syahindra, O. M. D., Khadijah, S., Dahliah, \& Aisyah, S. (2020). Menanamkan Karakter Kemandirian pada Saat Belajar Pada Anak Usia Dini di Taman Kanak-Kanak Aisyiyah Bustanul Athfal 02 Belawan. EDU RILIGIA: Journal of Islamic and Religious Education, $4(2), 170-182$.

Tissot, C., \& Evans, R. (2003). Visual teaching strategies for children with autism. Early Child Development and Care, 173(4), 425-433. https:/ / doi.org/10.1080/0300443032000079104

Utami, F. (2020). Pengaruh Metode Pembelajaran Outing Class Terhadap Kecerdasan Naturalis Anak Usia 5-6 Tahun. Jurnal Obsesi : Jurnal Pendidikan Anak Usia Dini, 4(1), 428-437. https://doi.org/10.31004/obsesi.v4i1.358 